\title{
INFORMACIONE TEHNOLOGIJE I SISTEMI KOMUNIKACIJA U SPORTU
}

Tamara Ratković

Univerzitet Singidunum, Beograd, Srbija
Odgovorno lice:

Tamara Ratković

e-pošta:

tratkovic@singidunum.ac.rs

\section{Rezime:}

Savremeno kompetetivno okruženje karakteriše prisustvo poslovnih, informacionih, društvenih, tehnoloških ili saobraćajnih sistema. Ono imperativno uslovljava efikasnu komunikaciju i to u smislu jačanja veze između megasistema sporta i okruženja. Zbog sve veće brzine kojom se inovacije stvaraju, razvijaju i šire, komunikatorima je bitno da prenesu informacije onima kojima su potrebne. Ključnu ulogu u tome ima primena informacione tehnologije (IT) i sistema komunikacija, procesa prenošenja informacija, ideja i emocija od pošiljaoca do primalaca posredstvom medija, a s ciljem određenih efekata. Rad nastoji da na sistematičan način oceni deluje li informaciono-komunikacioni sistem u skladu s ciljevima, i u kojoj meri efektivno i efikasno podupire ciljeve funkcionisanja sportskog sistema. S obzirom na rezultate analize sportske delatnosti, konkurentskog okruženja i lanca vrednosti menadžment određuje strategiju poslovanja i ciljeve koji je podržavaju. Strategije poslovanja i ciljevi predstavljaju ulazne promenljive u drugu fazu izrade strateškog plana ICS-a, čiji je fundamentalni zadatak da da odgovorna pitanje - kako se može uticati na ostvarenje ciljeva poslovanja i sprovođenje zacrtane strategije sportskog sistema. Informaciona tehnologija i sistem komunikacija nastoje da se potvrde u sportu poboljšanjem procesa i promenom organizacione strukture, uključivanjem IT u sve elemente sistema i povezivanjem sa drugim sistemima čiji je fundamentalni zadatak da dâ odgovor na gore pomenuto pitanje.

Ključne reči:

Informacija, komunikacija, komunikacioni sistem, sport, informaciona tehnologija.

\section{UVOD}

Ukoliko se razdoblja između jedinstvenih razvojnih trenutaka shvate kao "jedinice" ljudskog razvoja, postaje očigledno da ta vrsta stalnog, anti-entropijskog razvoja ljudskog roda zavisi u celini od otkrića i društvene primene novih naučnih i kulturnih ideja. Na tom tragu nastavlja se i Kuhnova koncepcija o potrebi naučnika da barataju jednim, manjeviše sveobuhvatnim korpusom generalizacija i eksplanatorskih obećanja, što implicira njegovo uverenje da te paradigme nisu samo teorijski sistemi, već i sistemi naučnih, metodoloških i socijalnih vrednosti. Pluralizaciju istraživačkih paradigmi trebalo bi shvatati kao prirodnu posledicu pluralizacije istraživačkih postupaka. U tom smislu, i sama 
istraživačka paradigma ima veću eksplikativnu moć u odnosu na prethodnu paradigmu i na budući razvoj u polju konkretne nauke [1]. Pri tome je i važna spoznaja o tome kako samo ona društva koja sprovode važan tehnološki napredak, pokazuju sposobnost za opstanak i prosperitet [2]. Ono što nedostaje jeste temeljni teorijski model onoga što je informaciono društvo zaista i kako su njegove tehničke, ekonomske, političke, kulturne i društvene implikacije međusobno povezane u procesu uspostavljanja međunarodnog programa informativne politike. Ukazuje li to da je došlo do još jednog kvantnog skoka unutar ponašanja informacija? Informaciona nauka, to ujedinjujuće teorijsko telo koje, osim njegovog snažnog jezgra usmerenog na korisnika, naglašava kontekstualno međusobno delovanje kognitivnih, društvenih, kulturnih, organizacionih, afektivnih i jezičnih činioca,i tvrdi da su fenomeni informacionog ponašanja, deo ljudskog komunikacijskog procesa [3]. Ovome treba dodati kako i sama informaciona nauka predstavlja ortogonalno područje koje ispituje informacije fenomena u različitim okruženjima pomoću interdisciplinarnih perspektiva [4].

U komunikološkom smislu paradigma se razvija u rasponu od početnog stepena, preko mreža (network) i grupa (cluster) do specijalizacije definisane čvrstoćom i kvalitetom međusobnih veza u komunikacionoj strukturi. Paradigmatska priroda društvenog sistema potvrđuje činjenicu da se strukturiranošću omogućava predviđanje procesa društvenog preokreta, a cirkularnošću sigurnost da će se društveni preokreti događati u budućnosti. Osim predvidljivosti procesa same revolucije i rezultata koji dolaze s njom, na ovaj način moguće je predvideti i ponašanje sistema koji kontroliše sliku sveta (društva) kroz određenu društvenu paradigmu [5]. Komunikologija uz pluralističke i monističke paradigme posebno naglašava paradigmatsku teoriju informacionog društva koja je prema opštim političkim i društvenim uverenjima njenih autora najbliža strukturalnom funkcionisanju. Održivost društva sigurno zavisi od razvoja osnovnih društvenih delatnosti i od odnosa između strukturnih elemenata teorijske koncepcije u društvu s izrazitim usmerenjem na komunikaciju kao važan element u koncepciji društva. Analiza pitanja vezanih za poslovne komunikacije, a u vezi s tim i pitanja sportskih komunikacija, moguća je ako se pre toga izvrši analiza obima i sadržaja pojma komunikacija ili komuniciranja, kako bi se kasnije prodrlo u jedan specifičan status sportskih komunikacija, a to su oni sadržaji komunikacija koji se ostvaruju u sportu i u vezi sa sportom [6]. Razvojem informacione tehnologije ostvaruju se brojne i raznovrsne mogućnosti čije se područje primene može naći i u sistemu sporta. Savremene informacione i (tele) komunikacione tehnologije imaju veliku i ključnu ulogu u organizaciji i delovanju sportskih sistema. Upravljanje telekomunikacionom i IT mrežom je vrlo važan segment poslovanja, predstavlja sve veći prioritet u poslovanju. Međutim, područje upravljanja postajaće sve veći prioritet i kod održavanja drugih mrežnih infrastrukturnih sistema. U tom smislu, budući naučni izazov predstavljaće transfer znanja, tehnika i protokola iz domena upravljanja telekomunikacionom mrežom uz ostale domene mrežnog upravljanja u sistemu sporta. U svakom slučaju tehnologija počinje da sazreva u sportskoj zajednici i postaje uobičajenija. Novi merni podaci, algoritmi i načini razmišljanja počinju da kruže, jer polje ulazi u razdoblje sazrevanja. Narednih decenija biće fascinantni.

\section{OPŠTE ODREDNICE INFORMACIONE TEHNOLOGIJE I KOMUNIKACIONOG SISTEMA}

Efikasno i efektivno upravljanje sistemom usmerava energiju na mali broj problema koji su relevantni, a veliki broj nevažnih problema trebalo bi zanemariti ili delegirati (sudionicima). Empirijski je potvrđen i visok stepen kontribucije informacionih sistema (engl. Information System-IS) delovanju svakog sistema. Time se zasigurno rasvetljava strateško značenje novih informacionih tehnologija (engl. Information Technology - IT) smanjivanjem troškova, akceleracijom administrativnih poslova, podsticanjem odlučivanja i uspešnijim i delotvornijim radnim procesima. Jer, u prirodi sistemskog mišljenja nalaze se dve stvari: konfuzija i otkriće reda [7].

\section{Informacije}

Kako u novije doba informacije predstavljaju ključni resurs poslovanja to se sve više govori i o IS-ima, njihovom projektovanju, izgradnji i funkcionisanju, o eksploziji informacija, informacionoj krizi, informacionoj podlozi poslovnog odlučivanja, informaciji kao sredstvu kontrole i sl. Informacija se povezuje s pitanjima prikupljanja, obrađivanja, pohranjivanja i dostavljanja korisnicima. Osnovom potrebe za razmenom što većih količina informacija u što kraćem vremenu kao opšte ljudske tendencije i potrebe koja dolazi od ljudskog nastojanja da se što efikasnije suprotstavi opštoj entropiji prirode, čovek izgrađuje sisteme komuniciranja koji mogu što bolje funkcionisati. Naravno, jedan 
stohastički proces sam po sebi nije informacija, nego je to kretanje iz jednog procesa u drugi, ako su među njima uspostavljene veze s težnjom da se oni izjednače. Pojam informacije mora se posmatrati sa multidimenzionalnih stanovišta (ne samo statističkih dimenzija). Informacija je mera vrednosti neke poruke donosiocu odluke u konkretnoj problemskoj situaciji, pri čemu se mogu razlikovati informacije spekulativnog tipa (impresije, ocene, verovatnosti, mišljenja), zatim informacije hibridnog tipa (kvalitativne, hipotetske, poluprecizne) i informacije znanstvenog tipa (precizne, određene, kvantitativne, egzaktne) [8]. Na vrednost informacija koja se procjenjuje na temelju koristi koju organizacija može imati upotrebom informacija, od značajnog su uticaja prikladnosti, kvalitet i količina informacija [9].

U odnosima poslovnih sistema s javnošću, komunikacija neretko podrazumeva uticanje na znanje, mišljenje i delovanje među većim i udaljenim skupinama. Zbog sve veće brzine kojom se inovacije stvaraju, razvijaju i šire, komunikatorima je bitno da prenesu informacije onima kojima su potrebne. Razvojni proces informacije započinje prikupljanjem činjenica i podataka (statističke vrednosti), a završava se uobičajenom analizom. Uopšteno, informacija je skup zaključaka izvedenih iz analize podataka o poslovanju organizacije $[9,510]$. Evidentno je da su neke informacije vrednije od drugih, a njihova se vrednost procenjuje na temelju koristi koju organizacija može imati ukoliko je iskoristi [10]. Što je veća korist, to je informacija vrednija. U tom smislu prikladnost, pravovremenost, kvalitet i količina predstavljaju glavne faktore koji određuju vrednost informacija. Utvrđivanje opravdanosti usvajanja informacija zahteva uspostavu procesa procenjivanja, što upućuje na sprovođenje cost-benefit analize tj. poređenje odnosa vrednosti koristi s utroškom stvaranja informacije.

\section{Informaciona tehnologija}

Opravdanim se čini posebno istaći značaj sposobnosti trajnog prilagođavanja sistema okolini i njihovih uticaja na okolinu u skladu sa svrhom i ciljevima. Naravno, to implicira sposobnost pravovremenog uočavanja nastajućih promena, spoznavanje potrebne upravljačke mere i sprovođenje primerene akcije, a zašta su preko potrebne strateške informacije i znanje $[11,85]$. Korišćenje znanja i intelektualnog kapitala sistema omogućava organizacijama donošenje kvalitetnijih odluka, veći udeo u razvoju inovacija, te adaptaciju i preživljavanje u novim okolnostima. Informaciona tehnologija je jedna od ključnih generičkih tehnologija jer prodire u sve sfere privrede, nauke, društvenog i privatnog života i u njih unosi radikalne promene [12]. Gotovo nemerljivo utiče na poslovanje i način rada kao i života ljudi, posebice značajnim trendovima promene načina rada unutar poslovne organizacije: rad u grupi, mogućnost rada izvan radnih mesta, nehijerarhijska organizacija rada i poveravanje dela posla spoljnim organizacijama. IT obuhvata opremu, programe i usluge čiji je cilj da pruži podatke, informacije i znanje pojedincima koji sudeluju u poslovnim procesima, te tako omogućiti ostvarenje strateških ciljeva organizacionog sistema. IT je uz ljudske resurse i organizacione promene jedan od ključnih elemenata u delovanju svakog organizacionog sistema. IT ima važnu ulogu u upravljanju znanjem što podupire brzi rast računarskih mreža i razvoj usluga koje se pružaju posredovanjem mreže [13], a u čemu važnu ulogu imaju strateški informacioni sistemi čija je osnovna svrha u tome da omogućavaju uspešniju upotrebu informacija u procesima odlučivanja, a koji se pojavljuju u strateškom upravljanju sistema.

Temeljena na primeni IT-e inovativna rješenja imaju svoj ograničeni rok trajanja. Iako predstavljaju osnovu konkurentske borbe, lako ih je kopirati ili kupiti, pa je konkurentska prednost proizašla njihovom upotrebom često kratkog veka (dok konkurenti ne uspeju implementirati sličan način odvijanja ključnih procesa). Na taj način takvi IS-i postaju osnova operacijske efikasnosti, a menadžment traži nove 'izvore' konkurentske prednosti kojima će se ponovno nepovratno promeniti struktura delatnosti [14]. Upotrebom IT-e organizacioni sistemi iniciraju promene strukture aktivnosti, postavljaju nove standarde poslovanja što im donosi prednost pred konkurentskim silama. Informatika tako strateški utiče na delovanje organizacije, ali i na čitavu strukturu delatnosti.

Informatička rešenja koja donose konkurentsku prednost ne moraju nužno promeniti strukturu delatnosti. Ona ubrzavaju i automatizuju određene procese ili smanjuju troškove poslovanja i time omogućuju izdvajanje od konkurenata bez promene strukture delatnosti. Primena IT-e u poslovanju ima vrlo jasan cilj: omogućiti organizaciono održivu konkurentsku prednost. Intenzivna primena IT-e u poslovanju može organizacijama omogućiti stvaranje prednosti pred konkurentima bržom reakcijom na tržišne uslove, boljim nivoom usluge, kontrolom troškova, poboljšanjem kvaliteta proizvoda/ usluge, globalizacijom poslovanja i stvaranjem strateških partnerstva. 


\section{Informacioni sistem}

Kao najvažniji pozitivni učinak tehnološkog razvoja, posebno u njegovom internetskom segmentu, pokazuje se stalan protok digitalnih, odnosno digitalizovanih informacija iz okruženja prema organizacionom sistemu i obrnuto. Gotovo svaki organizacioni sistem može pristupiti tekstualnim, brojčanim, zvučnim, grafičkim i video informacijama s bilo koje umrežene lokacije i plasirati vlastite informacije svih takvih oblika svim zainteresovanim, umreženim učesnicima. Bežične komunikacije i odgovarajući prenosivi uređaji omogućavaju da se to čini čak i u pokretu. Više nije problem kako doći do informacije - problem je šta s njima učiniti, odnosno kako ih iskoristiti. Ključni problem suvremenog poslovanja je kako iz mase uopšteno dostupnih informacija stvoriti korpus korisnog znanja [15].

Okvir koji naglašava planiranje uspeha i rezultata,te kontrolu na svim nivoima, ima sve karakteristike informacionog sistema. Uzima u obzir krajnju integraciju traženih pod-sistema poslovnih finansijskih i nefinansijskih informacija u sistemu [16]. Informacioni sistem predstavlja planirani, sistematični mehanizam koji menadžerima omogućuje pristup relevantnim informacijama na sistematičan način [17]. Informacioni sistem je sistem koji prikuplja, pohranjuje, čuva, obrađuje i isporučuje informacije važne za organizaciju, tako da postanu dostupne i upotrebljive svakome kome su potrebne. Informacioni sistem se može, ali ne mora, koristiti informacionom tehnologijom [13].

Posmatra li se s informaciono-komunikacijskog gledišta odnos organizacije s okolinom, tada se radi o analizi na nivou otvorenog sistema. Svaki poslovni sistem komunicira sa svojom okolinom pomoću svog informacionog sistema istraživanjem i prikupljanjem informacija o okolini, te razmenjivanjem informacija o svom delovanju. Proizlazi da je cilj IS-a dostavljanje prave informacije na pravo mesto u organizaciji, u pravo vreme i uz minimalne troškove. Imajući u vidu cilj, potrebno je podsetiti i na temeljne funkcije IS-a: (1) prikupljanje podataka; (2) obrada podataka; (3) spremanje podataka i informacija; i (4) dostavljanje podataka i informacija korisnicima [11].

Činjenici da sistem održava ulazne i izlazne informacione veze s okolinom, valja dodati i njihov upitan odnos u pogledu njihove količine i kvaliteta. Kako su informacione veze bitan činilac upravljanja sistemom, s upravljačkog stajališta razlikuju se upravljani, neutralni i upravljački informacioni sistemi [18]. Postavljanje IS-a u poslovnim sistemima implicira sledeće zadatke:
(1) služi kao strateško oružje; (2) služi za automatizovanje i integrisanje proizvodnih i poslovnih procedura koje bi se inače obavljale ručno; (3) služi kao podloga za upravljanje i rukovođenje, odnosno pruža informacije koje će menadžeri koristiti pri odlučivanju [11]. Da bi IS normalno funkcionisao, menadžeri bi trebalo da, uz analizu različitih vrsta potrebnih informacija za donošenje odluka, poštuju i određeni algoritam [19]. Za pravilan rad IS-a najpre treba definisati potrebe za informacijama, izabrati i prikupiti odgovarajuće podatke, sažeti i zatim analizirati podatke, izvršiti prenos informacija i na kraju koristiti informacije. Učinkovitost IS-a odnosi se na pomoć upravi u odlučivanju, pa je jedan od načina utvrđivanja potrebe za informacijama i analiza područja odlučivanja u kojima menadžeri donose odluke, analiza odluke svojstvene navedenim područjima odlučivanja koje menadžeri uistinu moraju doneti, i analiza alternativnih rešenja koje treba proceniti kako bi se donele specifične odluke [9].

Informacionim sistemima neophodno je upravljati na efikasan način, što podrazumeva upravljanje zadovoljstvom korisnika, ljudskim potencijalima na IS-u i sigurnošću IS-a. Samo s kompetentnošću zaposlenih u upravljanju navedenim aktivnostima moguće je povećati efikasnosti informacionog sistema od čega organizacija može imati znatnu korist. S druge strane, jedan od najvažnijih odrednica efikasnosti je stepen zadovoljstva zaposlenih ili korisnika informacionim sistemom (kvalitet IS-a i informacija). U upravljanju ljudskim potencijalima na informacijskom sistemu primetno je znatnije izmeštanje (engl. outsourcing), što je u skladu s korišćenjem prednosti rezanja troškova. Ipak, iskustva govore da je zbog brojnih činioca ovaj koncept vrlo osetljiv. Oslanjanjem na informacioni sistem povećava se osetljivost sistema na sigurnosna pitanja koja to prate. Gubitak vrednih podataka jedan je od najvećih rizika. I pored toga što se na globalnom nivou preduzimaju odgovarajuće mere zaštite kao što su npr. Opšteprihvaćena načela informacione sigurnosti (engl. Generally Accepted System Security Principle - GASSP), ostaje u znatnoj meri otvoren prostor za odgovarajuće permanentno delovanje svih odgovornih snaga u organizacionim sistemima.

\section{Komunikacija}

U interdisciplinarnoj komunikaciji, jedna disciplina potražuje od drugih samo pouzdana i za sebe korisna znanja i spoznaje. Kako takvih znanja i spoznaja ne može biti mnogo, interdisciplinarna komunikacija, 
koliko god da je plodna i korisna, ne može biti obilna. Da bi naučne informacije bile što prozirnije, njihove se poruke moraju oblikovati prema opštoj ljudskoj svesti. Komunikacioni lanac "predmet istraživanja - istraživač” se mora prestrojiti u lanac "čovek - čovek". Nauka o medijima je društvena nauka koja proučava ljudsko delovanje i socijalnu stvarnost koja je rezultat tog delovanja. Pod pojmom «društvene stvarnosti» shvatamo «sve elemente stvarnosti dostupne čoveku, koji nastaju ljudskim sudelovanjem, međusobnim zauzimanjem i borbom jednih protiv drugih, kao načini ponašanja, obrasci delovanja, uloge, sklopovi uloga, organizacije i institucije bilo koje kompleksnosti» [20]. Ali, u masovnoj komunikaciji kao prvenstvenom predmetu nauke o medijima, važno je istaknuti da osnovom novog tehničkog razvoja (npr. Internet) postaju sve važniji ostali oblici komunikacije (npr. komunikacija on-demand) [21]. Socijalni sistemi se mogu formirati i održavati samo ako su osobe učesnici međusobno povezani komunikacijom, jer se svako zajedničko delovanje pojedinaca temelji na prihvaćenim značenjima koja se prenose komunikacijom (lat. communicatio ne znači samo "priopštenje“ nego je to i „zajednica“ $i$,sudelovanje“).

Zbog činjenice da bez komunikacije nije moguće organizovano delovanje, pojam komunikacije prelazi u pojam „organizacije“ [22]. Primetno je neretko preklapanje pojmova interakcije i komunikacije, u smislu odnosa prema različitim oblicima istih socijalnih procesa, pri čemu interakcija označava formalna obeležja (učestalost, inicijativu, podređenost odnosno nadređenost, reciprocitet), a komunikacija sadržajne aspekte značenja [23]. Stoga, u najširem smislu interakcija koja je opsežnija od oba pojma, koristi se kao sinonim za socijalno delovanje, a komunikacija se definiše kao interakcija (socijalno djelovanje) pomoću simbola [24]. Takvim pojmovnim određenjem izbegava se i prividni problem o tome je li interakcija uslov komunikacije ili obrnuto.

Savremena nauka o komuniciranju analizom procesa komuniciranja zavisno od učesnika i njihove interakcije diferencira nekoliko nivoa komuniciranja [11]: (1) intrapersonalni nivo, (2) interpersonalninivo, (3) multipersonalni nivo, (4) nivo otvorenog sistema, (5) tehnološkinivo. S obzirom na to da se na intrapersonalnom nivou komuniciranja odvijaju intrinzični procesi, to se otvara prostor delovanja psihologije (psihološki procesi, mentalne aktivnosti, perciptivna obeležja) i medicine (fiziološka podloga procesa). Odnosima između pojedinaca u okviru manjih grupa, organizacijskih celina ili organizacija (interpersonalni i multipersonalni nivo komuniciranja) bavi se sociologija komuniciranja, odnosno komunikologija. Posmatra li se s informaciono- komunikacionog gledišta odnos organizacije s okolinom, tada se radi o analizi na nivou otvorenog sistema. Svaki poslovni sistem komunicira s okolinom pomoću svog informacionog sistema istraživanjem i prikupljanjem informacija o okolini, te razmenjivanjem informacija o svom delovanju. Na tehnološkom nivou analize, proces komuniciranja posmatra se $s$ aspekta bankarskih podataka i mreža elektroničkih računara. Reč je o izgradnji informacionih sistema za upravljanje i njihovih sastavnih delova, a za šta je nužno spoznati pravila i načela komuniciranja na pojedinim nivoima, čime se postaje ne samo bolji „komunikator“ nego i delotvorniji upravljač [11].

\section{Komunikacijski sistem}

Uspešna komunikacija je osnova svake transakcije i uspešnih odnosa, ne samo u poslovnim područjima poput marketinga i prodaje, logistike i upravljanja ljudskim potencijalima nego i u lokalnom okruženju te na globalnom nivou [25]. Komunikacioni sistem je sistem koji omogućava prenos poruka od izvora do primaoca, a sastoji se od izvora informacije (odašiljač), primaoca informacije (prijemnik) i sistema - posrednika (fizikalni kanali). Uspostavljanje i održavanje komunikacionoinformacionih tokova između organizacionog sistema i njegovih ciljnih grupa, primarni je zadatak tog sistema, a s ciljem međusobnog informisanja i razvoja dobrih odnosa, temeljenih na poverenju, privrženosti i lojalnosti. U samom procesu komunikacije s okruženjem, osnovni je cilj organizacionog sistema da obavesti korisnike i celokupnu javnost o svojoj ponudi i o poslovnim i društvenim aktivnostima kojima može zadovoljiti potrebe, želje i očekivanja okruženja.

Upravljanje i koordinacija s ukupnim procesom integrisanih komunikacija, predstavlja bitan uslov za stvaranje važnog organizacionog ugleda i reputacije. Komunikacioni procesi koji vode do razvoja kolektivnog poimanja organizacije mogu se sažeti u tri ključna aspekta: sudelovanje, reprezentiranje i subordinacija [26]. Zajedničko delovanje tih triju aspekata čini kolektivnu situaciju ili sistem aktivnosti. Razmena informacija mrežnom infrastrukturom stvara vrednost za obe ili čak sve strane u komunikacionom kanalu (pošiljalac, posrednik, primalac).

\section{KOMUNIKACIJA U SPORTU}

Savremeno društvo se bazira na četiri temeljna načela komunikacije, pri čemu je ona jeste i opažanje i očekivanje, postavlja zahteve, te je u velikoj meri u suprotnosti 
$\mathrm{s}$ informacijom, a opet u međusobnoj zavisnosti. Informacija je pretpostavka komunikacije i uvek je kodirana tj.,komunikacija može da ne zavisi od informacije. Proizlazi da najsavršenija komunikacija može biti čisto „podeljeno iskustvo" bez ikakve logike, pa stoga, primat ima percepcija, a ne informacija - za komunikaciju je potrebno zajedničko iskustvo [27]. Evidentno je da u globalnom socijalnom društvu nauka kao racionalni oblik društvene svesti, čija je osnovna društvena funkcija da na temelju proverenih saznanja komunicira $s$ predmetom saznanja i s onima kojima je to saznanje namenjeno, na specifičan način predstavlja bitan segment komunikacionog sistema. Komuniciranje se kao proces stvaranja, prenošenja i korišćenja informacija, operacionalizuje preko promena koje nastaju kod stvaraoca, prenosioca i subjekata komuniciranja, zatim promene koje nastaju u strukturi informacije,I promena koje su rezultat samog procesa komuniciranja. Komuniciranje kao proces razmene informacija ima svoju etiologiju u dimenziji sporta. U etiološkom smislu komuniciranje je dimenzija sportskog ponašanja, a sportsko komuniciranje dimenzija sporta. Sportsko komuniciranje je proces stvaranja, prenošenja i korišćenja sportskih informacija radi donošenja sportskih odluka, te prenošenja i ugrađivanja sportskih odluka u sportski sistem, odnosno njihovog razlaganja procesom poslovanja [6,77]. Jedan od bitnih faktora uspešnog upravljačkog sistema je i koncepcija komuniciranja koja se manifestuje kroz pitanja kao što su: Kada koga informisati? Ko to mora uraditi? Šta se želi tražiti i od koga? Efektivnu koncepciju sportskog komuniciranja moguće je ostvariti povećanjem stepena povezanosti, informisanošću putem štampe i informisanošću javnosti sa boljim obostranim razumevanjem. Pri tome su važne i određene pretpostavke poput opšte i sportske kulture kojima se oplemenjuje i usmerava sport,timovi i pojedinci. $S$ aspekta delatnosti, komunikacije čine temelj informacija o aktivnostima, elementima tih aktivnosti i o odnosima između aktivnosti, u strukturi delatnosti, između delatnosti i sistema, i između sistema. Svi se odnosi temelje na relevantnim informacijama o njima samima jer sportska delatnost, kao polazna sociološka kategorija, svoje elemente formira u konstelaciji autonomnih sociogenih faktora, kao i mikro i makro-relacija $[6,103]$. Sasvim je očigledno kako je raspon medijskih mogućnosti izrazito širok i stalno raste, ali i uz spoznaju o fenomenu isprepletenosti, ipak se može razmišljati o usmenim, pisanim, vizualnim ili elektronskim (koji često kombinuju nekoliko medijskih tipova) medijskim kategorijama $[28,101]$ :
- Usmeni mediji. Ova vrsta medija uključuje razgovore licem u lice, intervjue, govore, lične prezentacije i sastanke, čime se poslovnim komunikatorima omogućava komunikaciona delotvornost visokog stepena kroz vidljivost, čujnost i obostrano reagovanje. Usmena komunikacija je najbolja kada treba ohrabriti interakciju, izraziti osećanja ili pratiti emocionalne reakcije.

- Štampani mediji. Pisane poruke mogu imati razne oblike, od tradicionalnih memoranduma, preko pisma, do preciznih izveštaja koji kvalitetom svoje izrade konkurišu časopisima.

- Vizuelni mediji. Za brojne sportske komunikatore vizualni su elementi dominantni i potpomognuti malim količinama teksta. U tom kontekstu, vizualnim medijima može se smatrati svaki oblik u kome jedan ili više vizualnih elemenata igra središnju ulogu u prenošenju sadržaja poruke. Poruke kombinovane snažnim vizualnim elementima s podupirućim tekstom mogu biti delotvorne, posebno u opisivanju kompleksnih ideja i procesa, smanjivanju komunikacionih barijera smanjivanjem potrebe jezičke obrade, kao i čisto tekstualnih opisa ili objašnjenja.

- Elektronički mediji. Raspon elektroničkih medija je veliki i kontinuirano nastavlja da raste, od telefonskih poziva i podkastova do blogova, vikija, epošte i tekstualnih poruka. Korišćenje elektroničkih medija može povećati uzbuđenje i vizualnu privlačnost svojom interaktivnošću, animacijom, zvučnim i video zapisom.

U savremenom sportu, od elektronskih medija najčešći su:

- Elektronske verzije usmenih medija (telefonski pozivi, telekonferencije, poruke glasovne pošte, audio snimci, glasovno sintetiziranje, glasovno prepoznavanje i animirani onlajn likovi);

- Elektronske verzije štampanih medija (e-pošta, IM-ovi, blogovi, veb stranice, društvene mreže i vikiji);

- Elektronske verzije vizualnih medija (elektronske prezentacije, kompjuterske animacije i video zapisi).

Uvažavajući sve prethodne opservacije može se zaključiti da je integrisana sportska komunikacija mnogo više nego integracija promotivnih elemenata ili spleta elemenata marketinških komunikacija.

Želi li se sportsko komuniciranje sagledati u ukupnom kontekstu, tada je fokus potrebno usmeriti na 
specifičnu razmenu misli i poruka između učesnika unutar organizacije, odnosno između učesnika i spoljnog okruženja organizacije, na načelima interakcije, dvosmernosti i razumevanja. Sportsko komuniciranje zasigurno zahteva sistemski pristup pri čemu se naročito ističu organizacijske sinergije: tržišne (komplementarnost produkata), tehnološke (transfer znanja), troškovne i menadžerske (transfer ukupnog znanja). Razmatranjem sportskog komuniciranja na holistički način približavamo se integrisanju ekonomije koju nedvosmisleno pogone pokretači $[29,9]$ : (1) informacije daju najveću dodatnu vrednost; (2) nebitne su fizičke udaljenosti; (3) brzina je ključna; (4) glavnu imovinu čine ljudi i kapital ljudskog uma; (5) umrežavanje poslovnih partnera i kupaca je ubrzavač poslovnog rasta; (6) u odnosu na tržišne udele vrednosti u umreženim ekonomijama rastu eksponencijalno; (7) sposobnost upravljanja informacijama determinira tržišnu snagu; (8) snaga tržišta preusmerava se na korisnika/publiku; (9) Internet omogućava komunikaciju s pojedinačnim korisnicima/kupcima; (10) potrošači jasnije prepoznaju vrednosti i razvijaju posebne odnose. S obzirom na prethodno naglašeni potrebni sinergizam i prvog pogonskog pokretača, upravljanje sportskim informacijama uslovljeno je potpornim informacijama ukupnoj strategiji. Kako potrebne informacije zavise od strateških ciljeva, samom promenom strateških ciljeva određuje se dodatno druga vrsta potpornih informacija.

\section{ZAKLJUČAK}

Socijalni sistem kao otvoreni sistem komunicira sa svojom okolinom i razmenjuje materiju, energiju i informacije. Kvalitetna obrada informacija unutar svakog socijalnog sistema i ostvarenje celovitih komunikacionih mreža za uzajamno povezivanje između elemenata društvene organizacije, temelj su sistemsko-procesnog spoznavanja i rešavanja problema. Svaki sportski system komunicira sa svojom okolinom uz pomoć svog informacijskom sistema istraživanjem i prikupljanjem informacija o okolini, te razmenjivanjem informacija o svom delovanju. Cilj informacionog sistema je dostaviti pravu informaciju na pravo mesto u sportskom sistemu, u pravo vreme i uz minimalne troškove.

Za izradu kvalitetnog informaciono-komunikacionog sistema, potrebno je poznavanje svih procesa koji se na njega odnose. U tome je preko potrebna saradnja svih učesnika, a najvažniju fazu razvoja IC sistema čini analiza koja mora biti temeljna i detaljna jer su propusti, koji u ovoj fazi mogu nastati, gotovo nenadoknadivi.
Informaciona tehnologija dramatično menja društvo u kojem živimo. Ona, kao ni jedna druga tehnologija, traži da menadžeri maštovito i kreativno gledaju na budućnost, posebno kad se radi o strateškim ciljevima ili novim konceptima racionalizacije, unapređenja kvaliteta i poslovne uspešnosti.

Novi pristupi sportskim komunikacijama zasnivaju se na napuštanju tradicionalnog koncepta masovne komunikacije i prelasku na ciljani pristup u komunikaciji sa postojećim i potencijalnim učesnicima i pripadnicima drugih ciljnih komponenti sistema sporta.

\section{LITERATURA}

[1] Kuhn, T. (1996). The Structure of Scientific Revolutions. Chicago: The University of Chicago Press.

[2] LaRouche, J. H. (1984). So, You Wish to Learn All About Economics? A Text on Elementary Mathematical Economics. New York: New Benjamin Franklin House Publishing Company, Inc.

[3] Pettigrew, E. K., Fidel, R. \& Bruce, H. (2001). Conceptual Frameworks in Information Behavior. Annual Review of Information Science and Technology (ARIST), 35, str. 43-79.

[4] Bates, J. M. (1999). The Invisible Substrate of Information Science. Journal of the American Society for Information Science, 50(12), pp. 1043-1050.

[5] Žugić, Z. (2000). Sociologija sporta. Zagreb: Fakultet za fizičku kulturu Sveučilišta u Zagrebu.

[6] Bjelica, B. S. \& Bjelica, J. D. (2006). Komunikacije u sportu. Podgorica - Nikšić: Filozofski fakultet, Nikšić i Crnogorska sportska akademija, Podgorica.

[7] Churchman, C. W. (1968). The Systems Approach. New York: Delacorte Press.

[8] Srića, V. (1990). Informatički inženjering i menadžment. Zagreb: Društvo za razvoj informacijske pismenosti (DRIP).

[9] Certo, C. S. \& Certo, T. S. (2012). Modern management: concepts and skills. New Jersey: Pearson Education, Inc.

[10] Gregory, H. R. \& Van Horn, L. R. (1974). "Value and Cost of Information". U: Conger, J. \& Knapp, W. R. (Eds.), Systems Analysis Techniques (str. 473.-489.). New York: Wiley.

[11] Srića, V., Pavlić, M. \& Treven, S. (1994). Menedžer i informacijski sustavi. Zagreb: Poslovna knjiga d.o.o.

[12] Budin, L. (1993). O hrvatskom nazivlju u području računarstva i informacijske tehnologije. Journal of Computing and Information Technology, 1, str. 75.-78. 
[13] Bosilj Vukšić, V., Čerić, V. \& Varga, M. (2004). Informacijska tehnologija u poslovanju. Zagreb: Element.

[14] Panian, Ž., Spremić, M. i sur. (2007). Korporativno upravljanje i revizija informacijskih sustava. Zagreb: Zgombić \& Partneri - nakladništvo i informatika d.o.o.

[15] Panian, Ž. (2003). Izazovi elektroničkog poslovanja. Zagreb: Narodne novine.

[16] Holmes, W. R. (1970). Twelve Areas to Investigate for Better MIS. Financial Executive, p. 24.

[17] Laudon, C. K. \& Laudon, P. J. (1993). Management Information Systems: Organization and Technology. New York: Macmillan.

[18] Panian, Ž. (1999). Poslovna informatika. Zagreb: Informator.

[19] Lederer, A. \& Gardner, V. (1992). Meeting Tomorrow's Business Demands through Strategic Information Systems Planning. Information Strategy: The Executive's Journal, (1:2), str. 20.-27.

[20] Patzelt, J. W. (1986). Sozialwissenschaftliche Forschungslogik. München / Wien: Oldenbourg: Einführung.

[21] Kunczik, M. \& Zipfel, A. (2006). Uvod u znanost o medijima i komunikologiju. Zagreb: Friedrich Ebert Stiftung.
[22] Cherry, C. (1967). Kommunikationsforschung eine neue Wissenschaft. Frankfurt am Main: S. Fischer Verlag.

[23] Blau, M. P. \& Scott, W. R. (1963). Formal Organizations: A Comparative Approach. Redwood City, CA: Stanford University Press.

[24] Weber, M. (1972). Wirtschaft und Gesellschaft. Grundriß der verstehenden Soziologie. Tübingen: J.C.B. Mohr (Paul Siebeck).

[25] Hinner, M. B. (2002). Communication Science: An Integral Part of Business and Business Studies? Freiberg Working Papers, 13, str. 4.

[26] Spender, J. C. (1998). The Dynamics of Individual and Organizational Knowledge. U: Eden, C. \& Spender, J. C. (ur.), Managerial and Organizational Cognition: Theory, Methods and Research. Thousand Oaks: Sage Publications.

[27] Drucker, F. P. (2001). The Essential Drucker. New York, NY: HarperCollins Publishers, Inc.

[28] Thill, V. J. \& Bovée, L. C. (2013). Excellence in Business Communication. New Jersey: Pearson Education, Inc.

[29] Roberts, M. L. (2003). Internet Marketing. New York: McGraw-Hill. 